\title{
Correction: Impaired cortical processing of inspiratory loads in children with chronic respiratory defects
}

\author{
Brigitte Fauroux*1,2,7, Francis Renault ${ }^{3}$, Pierre Yves Boelle ${ }^{4}$, Christine Donzel- \\ Raynaud $^{5}$, Frédéric Nicot ${ }^{2}$, Annick Clément ${ }^{1,2}$, Christian Straus ${ }^{5,6}$ and \\ Thomas Similowski 5,6
}

\begin{abstract}
Address: ${ }^{1}$ AP-HP, Hôpital Armand Trousseau, Pediatric Pulmonary Department, Paris, 75571, France, 2Inserm UMR-S 719, Paris, 75000, France, Université Pierre et Marie Curie-Paris, 75571, France, ${ }^{3}$ AP-HP, Hôpital Armand Trousseau, Pediatric Neurophysiology Department, Paris, 75571 , France, ${ }^{4}$ AP-HP, Hôpital Saint Antoine, Department of Biostatistics, 75012 Paris, Inserm U444, 75000, Paris, France, ${ }^{5}$ AP-HP, Hôpital La Pitié Salpétrière, Respiratory Physiology, Pulmonology and Intensive Care, Paris, France, ${ }^{6}$ UPRES EA 2397, Université Pierre et Marie Curie-Paris, Paris, France and 7Pediatric Pulmonary Department and Research Unit Inserm UMR-S 719, AP-HP, Hôpital d'Enfants Armand Trousseau, 26 avenue du Docteur Arnold Netter, 75571 Paris Cedex 12, France
\end{abstract}

Email: Brigitte Fauroux* - brigitte.fauroux@trs.aphp.fr; Francis Renault - francis.renault@trs.aphp.fr; Pierre Yves Boelle - pierreyves.boelle@sat.aphp.fr; Christine Donzel-Raynaud - christine.raynaud@psl.ap-hop-paris.fr; Frédéric Nicot - fred.nicot@laposte.net; Annick Clément - annick.clement@trs.aphp.fr; Christian Straus - christian.straus@psl.aphp.fr;

Thomas Similowski - thomas.similowski@psl.aphp.fr

* Corresponding author

Published: 23 February 2008

Respiratory Research 2008, 9:22 doi:10.1186/1465-9921-9-22
Received: 13 February 2008

Accepted: 23 February 2008

This article is available from: http://respiratory-research.com/content/9///22

(c) 2008 Fauroux et al; licensee BioMed Central Ltd.

This is an Open Access article distributed under the terms of the Creative Commons Attribution License (http://creativecommons.org/licenses/by/2.0), which permits unrestricted use, distribution, and reproduction in any medium, provided the original work is properly cited.

We would like to make it clear that part of the cohort of patients used in our study [1] was also analysed in an article published in Clinical Neurophysiology [2]. Although this study was cited in the original version of our article as reference 15, we feel that the overlap between the two studies should be made plain.

\section{References}

I. Fauroux B, Renault F, Boelle PY, Donzel-Raynaud C, Nicot F, Clément $A$, Straus $C$, Similowski T: Impaired cortical processing of inspiratory loads in children with chronic respiratory defects. Respir Res 2007, 8:61.

2. Nicot F, Renault F, Clement A, Fauroux B: Respiratory-related evoked potentials in children with asthma. Neurophysiol Clin 2007, 37:29-33.
Publish with Biomed Central and every scientist can read your work free of charge

"BioMed Central will be the most significant development for disseminating the results of biomedical research in our lifetime."

Sir Paul Nurse, Cancer Research UK

Your research papers will be:

- available free of charge to the entire biomedical community

- peer reviewed and published immediately upon acceptance

- cited in PubMed and archived on PubMed Central

- yours - you keep the copyright
BioMedcentral 